\title{
Effect of Packaging Material on the Postharvest Life of Cut Rose cv. 'First Red'
}

\author{
V. Vijaya Bhaskar* and P. Venkata Rao
}

Department of Horticulture, College of Agriculture, Acharya N. G. Ranga Agricultural University, Rajendranagar, Hyderabad-500 030, Andhra Pradesh, India

*Corresponding author

\section{A B S T R A C T}

\section{Keywords}

Rose, Packaging material, Water potential,

Enzymatic changes,

Vase life

Article Info

Accepted:

10 December 2017

Available Online:

10 January 2018
Cut roses were pulsed with the best pulsing combination of $\mathrm{Al}_{2}\left(\mathrm{SO}_{4}\right)_{3} 400 \mathrm{ppm}$ in combination with Sucrose $4 \%$ (arrived during the previous pulsing experiments) at room temperature $\left(22 \pm 2^{\circ} \mathrm{C}\right)$ for 24 hours and then packed with different packaging material and stored at $2-4^{\circ} \mathrm{C}$ for 5 days and then evaluated for their vase life. Among the different packaging material tried polythene sheet in combination with corrugated fibre board boxes (PS+CFB) followed by tissue paper in combination with corrugated fibre board boxes $(\mathrm{TP}+\mathrm{CFB})$ increased vase life (10.2 and 10.0 days respectively) and maintained normal flower opening and quality of the flower by lowering the activities of respiratory enzymes as well as limiting the gaseous exchange during storage when compared with other treatments.

\section{Introduction}

Rose has been considered as the strongest competent among the cut flowers both in the domestic as well as international trade. Its demand has increased greatly in the semiurban and urban areas all over the world. However, low keeping quality of cut roses badly affected the growers as well as the traders in the recent past in India. In the commercial use of cut flowers, it is usually the life span of the petals which determine the effective life of the flower, but petals are generally short lived owing to their tenderness and delicate nature leading to rapid deterioration in quality and ultimately shorten the vase life. Generally, cut flowers carry-on all life processes at the expense of stored reserve food in the form of carbohydrates, proteins and fats, limiting their longevity and pose problems in handling and marketing. Since water relations play an important role in the postharvest physiology and biochemistry of cut flowers, the continuity of water to the cut flower should be ensured. Apart from these, treatment of cut flowers with chemicals can reduce the effect of ethylene and enzymatic changes, which ultimately reduces the senescence of petals there by enhance the cut flower life. Keeping these things in view, 
the present investigation was aimed to find out the effect of pulsing and packaging material on the senescence of cut roses during vase life period.

\section{Materials and Methods}

Flowers of rose (Rosa hybrida L.) cv. 'First Red' obtained from a commercial green-house located near Hyderabad, $12 \mathrm{~km}$ away from the ANGRAU campus were used for the experimentation. Rose flower stalks/shoots of about $50 \mathrm{~cm}$ in length were harvested when the first petal was unfurling and ready to open. The flower stems were harvested in the morning to avoid excessive heat and immediately the flowers were held in deionized water and handled uniformly before treatment. The flowers were brought to the laboratory within two hours after harvest. Flower stems were trimmed under water to 45 $\mathrm{cm}$ and all the leaves except 2 to 3 compound leaves below the flower bud, were removed to avoid contact with the solution (Buys, 1969). The flower stalks were placed in the best pulsing treatment solution arrived during the previous pulsing experiment i.e., $\mathrm{Al}_{2}\left(\mathrm{SO}_{4}\right)_{3}$ $400 \mathrm{ppm}+$ Sucrose $4 \%$ at room temperature $\left(22 \pm 2^{\circ} \mathrm{C}\right)$ for 24 hours and then packed with different packaging material viz., Polythene Sheet + CFB (PS+CFB), Cellophane Paper + $\mathrm{CFB}(\mathrm{CP}+\mathrm{CFB})$, Tissue Paper + CFB $(\mathrm{TP}+$ $\mathrm{CFB})$, News Paper $+\mathrm{CFB}(\mathrm{NP}+\mathrm{CFB})$ and Kraft Paper + CFB $(\mathrm{KP}+\mathrm{CFB})$ and stored at 2$4^{\circ} \mathrm{C}$ for 5 days. During packaging each CFB box ( 2 ply) was filled with 3 bunches i.e., 60 flowers (60 flowers per treatment). The CFB box dimensions were $60 \mathrm{~cm}$ x $30 \mathrm{~cm}$ x $15 \mathrm{~cm}$ and contained 4 holes ( 2 holes each side in the opposite direction) with $1.5 \mathrm{~cm}$ diameter. After 5 days of storage at $2-4^{\circ} \mathrm{C}$, the flowers were brought back to room temperature and placed in distilled water for the rest of the experiment to evaluate their vase life. The flowers were continuously held in distilled water till the end of vase life. Each conical flask held 5 flowers and considered a replication. The individual flower stems were placed randomly in the $500 \mathrm{ml}$ conical flask containing $300 \mathrm{ml}$ of distilled water. The narrow mouth of the conical flask was sealed with non-absorbent cotton, which effectively prevented the evaporational loss of water. All the treatments replicated thrice in a completely randomized design with factorial concept. The observations on electrolyte leakage (EL), water potential $\left(\psi_{\mathrm{w}}\right)$, catalase activity (CAT), peroxidase activity (POD), flower opening, flower diameter and vase life were recorded by adopting the methods as explained by Bhaskar et al., (2005). The data were subjected to statistical analysis as per the procedure outlined by Panse and Sukhatme (1978). The results were analyzed using analysis of variance (ANOVA) and F-test analysis. Least significant difference was used for comparison between the treatments.

\section{Results and Discussion}

The changes in EL during vase life period of cut rose cv. First Red, packed with different packaging material was presented in Table 1. The rose flowers packed with different packaging material differed significantly with a maximum EL (49.083) recorded with $\mathrm{NP}+\mathrm{CFB}$, whereas, $\mathrm{PS}+\mathrm{CFB}$ recorded significantly least EL (37.868), followed by CP+CFB (43.194). There were significant differences in EL during different days of vase life period. The EL significantly increased at each successive interval of observation throughout the vase life period. The interaction effect on EL between days and treatments was also significant. The EL continuously increased in all the treatments, whereas, the increase was gradual in PS+CFB. A rapid increase was observed in $\mathrm{NP}+\mathrm{CFB}$ after day 4. The improved water relations with $\mathrm{PS}+\mathrm{CFB}$ and $\mathrm{CP}+\mathrm{CFB}$ have reduced the electrolyte leakage. 
The changes in $\psi_{\mathrm{w}}$ during vase life period of cut rose cv. First Red, packed with different packaging material was presented in Table 2. The flower stalks packed with different packaging material differed significantly with a least $\psi_{\mathrm{w}}(-11.556)$ recorded with $\mathrm{NP}+\mathrm{CFB}$, whereas, $\mathrm{PS}+\mathrm{CFB}, \mathrm{TP}+\mathrm{CFB}$ and $\mathrm{CP}+\mathrm{CFB}$ recorded significantly higher $\psi_{\mathrm{w}}$ with no significant differences among themselves. There were significant differences in the $\psi_{\mathrm{w}}$ during different days of vase life period. The $\psi_{\mathrm{w}}$ significantly decreased at each successive interval of observation with passage of time during vase life period. The interaction effect on $\psi_{\mathrm{w}}$ between days and treatments was also significant. The $\psi_{\mathrm{w}}$ continuously decreased in all the treatments, but the decrease was gradual in $\mathrm{PS}+\mathrm{CFB}, \mathrm{TP}+\mathrm{CFB}$ and $\mathrm{CP}+\mathrm{CFB}$, whereas, it was rapid in NP+CFB after day 4. Reduced electrolyte leakage due to improved water relations with $\mathrm{PS}+\mathrm{CFB}, \mathrm{TP}+\mathrm{CFB}$ and $\mathrm{CP}+\mathrm{CFB}$ led to improved water potential in the cut rose spikes.

The changes in CAT activity during vase life period of cut rose cv. First Red packed with different packaging materials were presented in Figure 1. There were no significant differences in the CAT activity with different packaging material treatments. There were significant differences in the CAT activity during different days of vase life period. On day 11, there was a significant decrease in CAT activity, whereas, in the remaining all other days there were no significant differences. The interaction effect on CAT activity between days and treatments was also significant. On day $7, \mathrm{NP}+\mathrm{CFB}$ recorded significantly highest (0.041) CAT activity when compared with all other treatments. The CAT activity was almost constant during vase life period in many of the treatments. The CAT activity increased when the flowers reached to senescence stage.

The changes in POD activity during vase life period of cut rose cv. First Red packed with different packaging materials were presented in Figure 2. The rose flowers packed with different packaging materials differed significantly with a highest POD activity (0.045) recording with $\mathrm{NP}+\mathrm{CFB}$, whereas, significantly lowest POD activity (0.031) recorded with PS+CFB. There were significant differences in the POD activity during different days of vase life period. On day 1 , the POD activity was significantly highest (0.045), whereas, on day 3 it was significantly decreased when compared with day 1 . On day 5, there was no significant difference when compared with day 3 . On day 7 , there was a significant increase in POD activity (0.043) when compared with day 5 and since then POD activity significantly decreased at each successive interval of observation till the end of vase life period. The interaction effect on POD activity between days and treatments was also significant. On day $1, \mathrm{TP}+\mathrm{CFB}, \mathrm{NP}+\mathrm{CFB}$ and $\mathrm{KP}+\mathrm{CFB}$ recorded significantly higher POD activity, whereas, PS+CFB recorded significantly lowest POD activity. On day 3, KP+CFB recorded significantly highest (0.042) POD activity, whereas $\mathrm{PS}+\mathrm{CFB}$ recorded significantly lowest (0.028) POD activity. On day $5, \mathrm{NP}+\mathrm{CFB}$ recorded significantly highest (0.045) POD activity, whereas, PS+CFB recorded significantly lowest (0.028) POD activity. On day 7, KP+CFB recorded significantly lowest (0.038) POD activity, whereas, there were no significant differences in the remaining all other treatments. On day 9, NP+CFB recorded significantly highest (0.054) POD activity, whereas, TP+CFB recorded significantly lowest (0.030) POD activity. On day 11, PS+CFB recorded significantly lowest POD activity, whereas, there were no significant differences in the remaining treatments.

The POD activity in PS+CFB was found significantly lowest when compared with other treatments throughout the vase life 
period, whereas, in the remaining treatments there was no rhythm and continued with fluctuations in the POD activity. Halevy and Mayak (1979) reported that two major metabolic events occur in senescing petals, increase in respiration and hydrolysis of cell components. The enzymatic changes found during petal senescence are associated mainly with these two processes.

Table.1 Effect of packaging material on electrolyte leakage (\%) during vase life period of cut rose cv. First Red

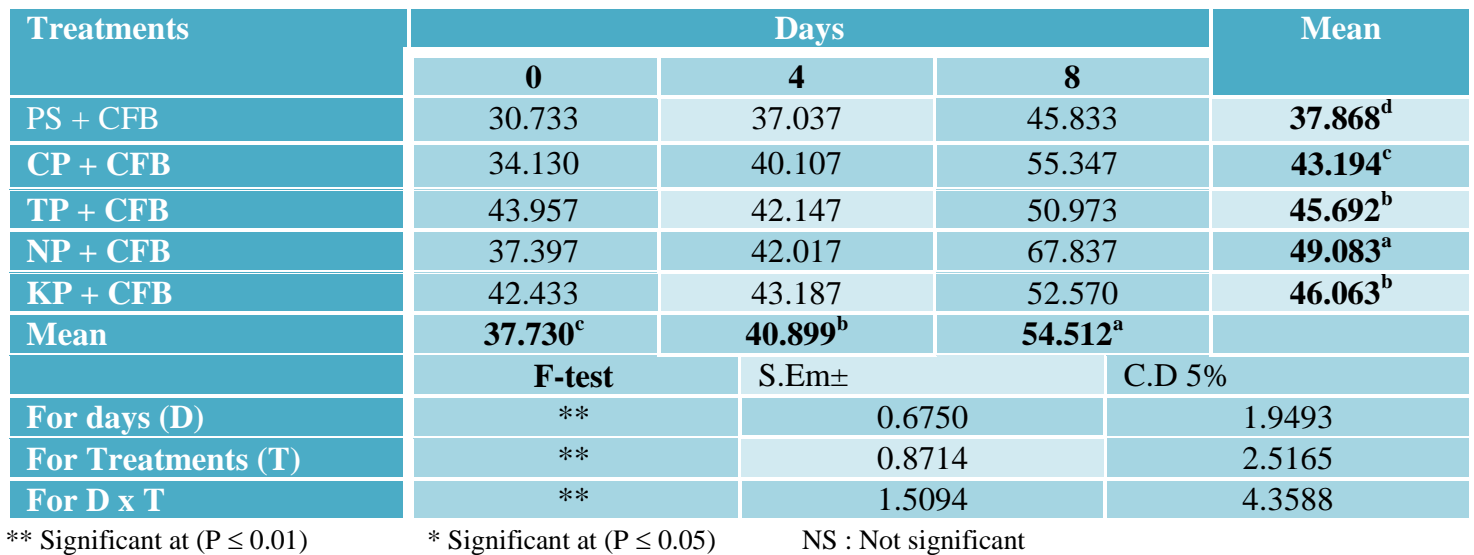

Figures bearing same superscripts did not differ significantly

Table.2 Effect of packaging material on peduncle water potential (-bars) during vase life period of cut rose cv. First Red

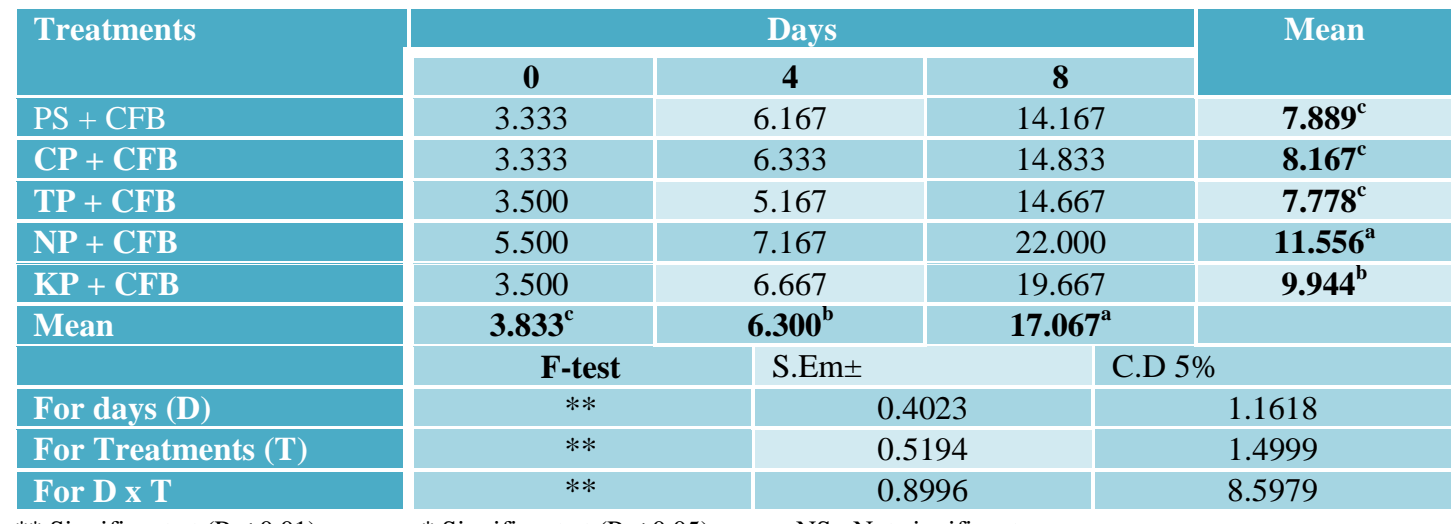

** Significant at $(\mathrm{P} \leq 0.01) \quad *$ Significant at $(\mathrm{P} \leq 0.05)$

Figures bearing same superscripts did not differ significantly

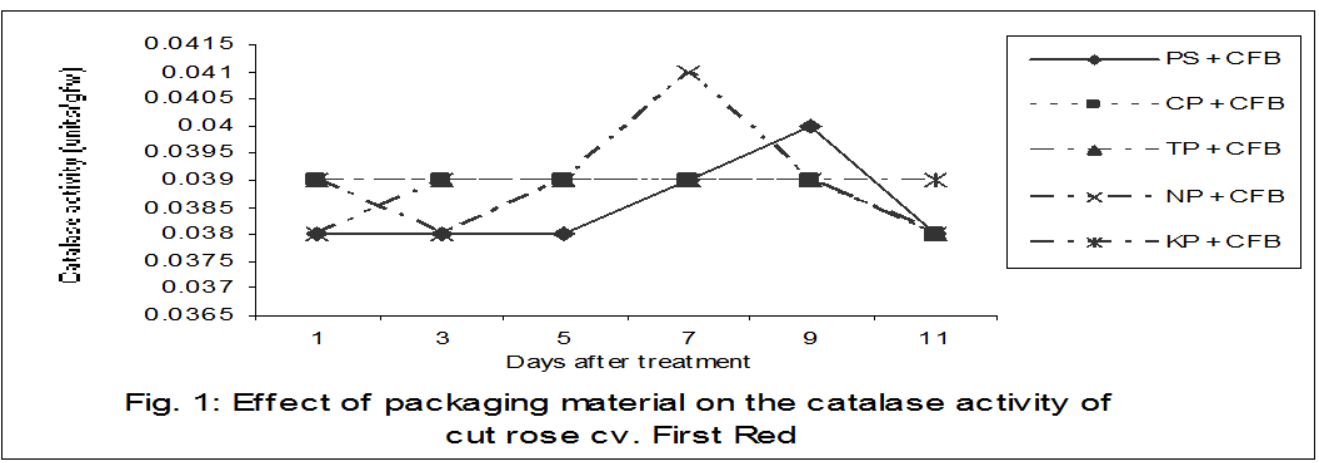




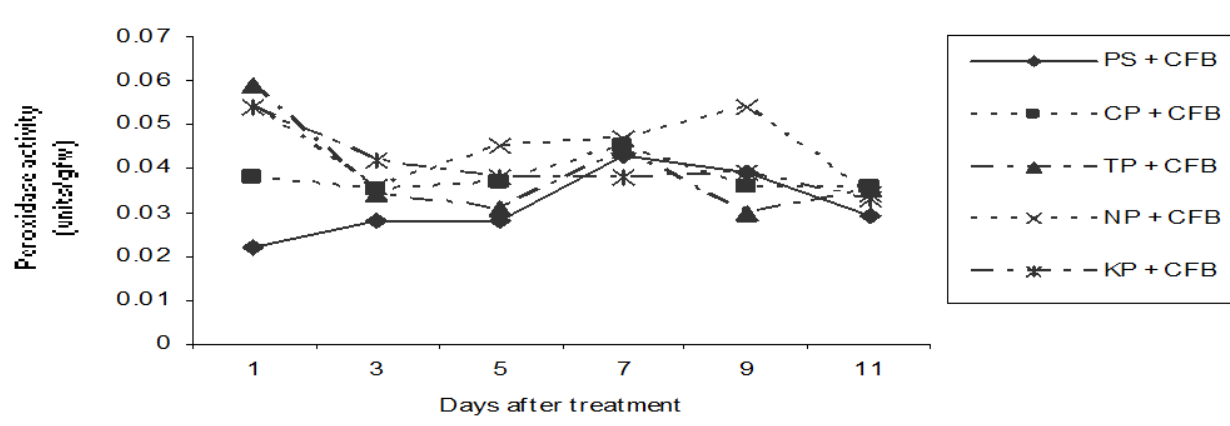

Fig. 2: Effect of packaging material on the peroxidase activity of cut rose cv. First Red

Fig.3 Effect of packaging material on flower opening (through scale 1 to 7 ) of cut rose cv. First Red
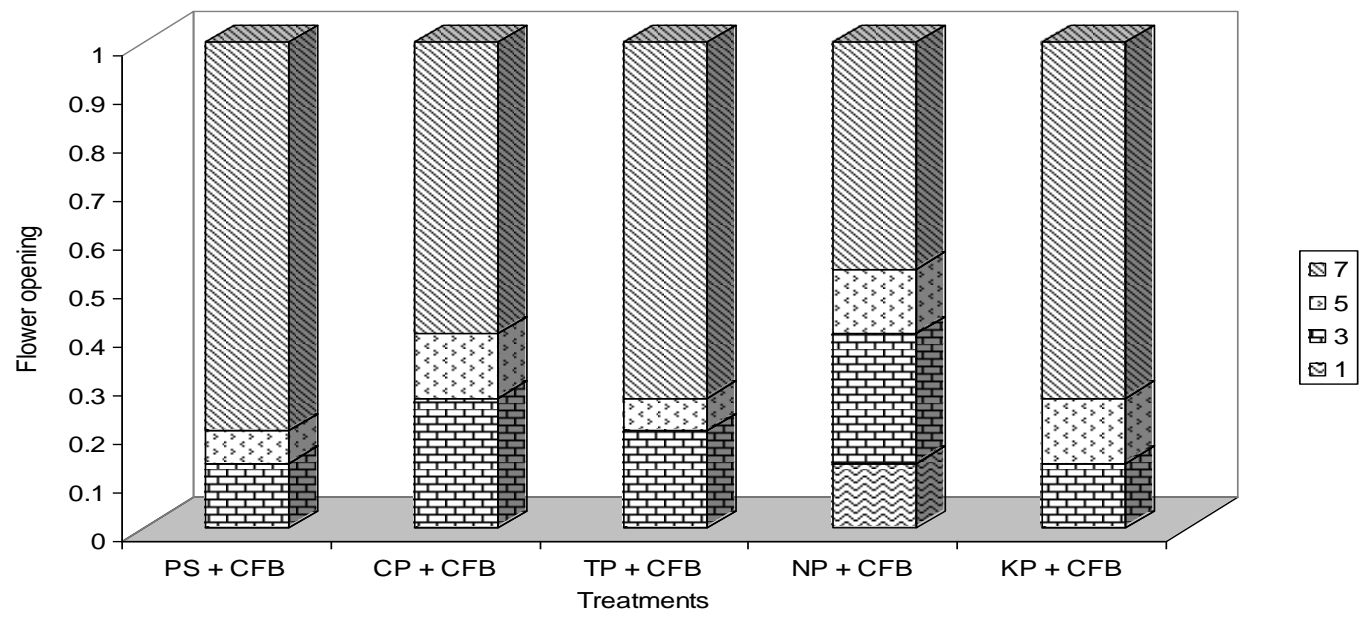

Fig.4 Effect of packaging material on flower diameter $(\mathrm{cm})$ and vase life (days) of cut rose cv. First Red

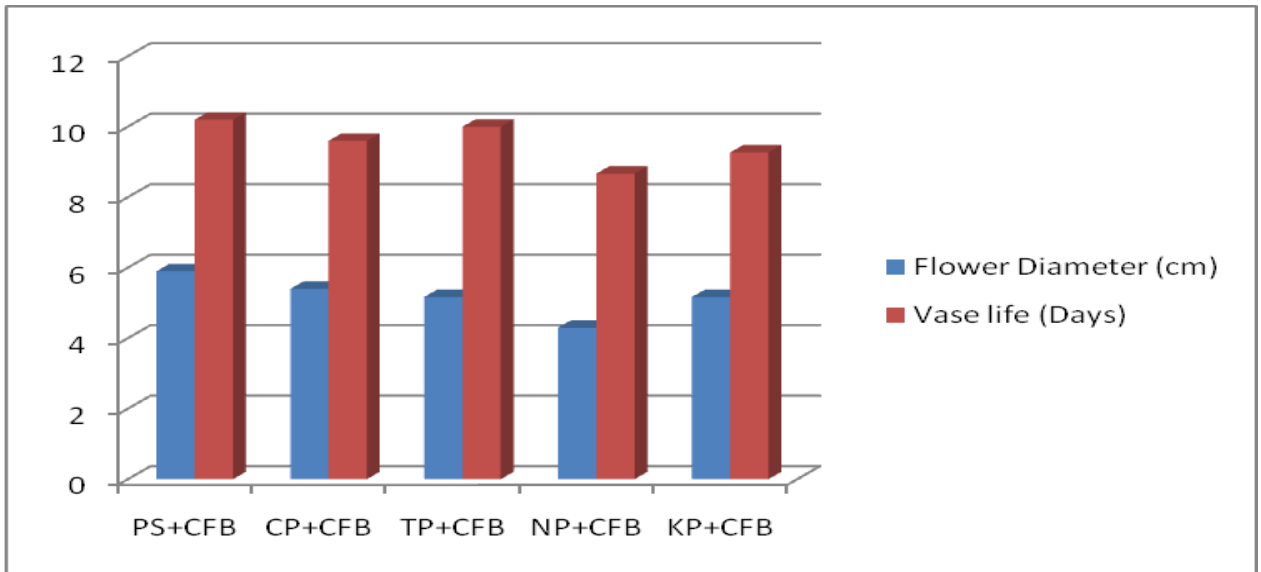


The changes in flower opening during vase life period of cut rose cv. First Red packed with different packaging material was depicted in Figure 3. The flowers pulsed with $\mathrm{Al}_{2}\left(\mathrm{SO}_{4}\right)_{3} 400 \mathrm{ppm}+$ Sucrose $4 \%$ and then packed with different packaging material expressed marked differences in the degree of flower opening. Among all the packaging materials tried, flowers packed with PS+CFB recorded increased degree of flowering when compared with all other packaging materials used during the vase life period. The improved water relations with $\mathrm{PS}+\mathrm{CFB}$ enhanced the tissue water potential in the cut rose flowers there by reduced the electrolyte leakage, thus improved the flower opening.

The changes in flower diameter and vase life during vase life period of cut rose cv. First Red, packed with different packaging material was presented in Figure 4. Among the packaging material treatments, polythene sheet in combination with CFB recorded maximum flower diameter (5.90) and vase life (10.2). Newspaper in combination with CFB recorded lowest flower diameter (4.30) as well as vase life (8.67). The increased flower diameter and vase life with $\mathrm{PS}+\mathrm{CFB}$ were due to increased water potential and reduced electrolyte leakage in the cut rose stems. The present results were in confirmation with Bhattacharjee (1997) who expressed that packing in thin foil or polythene helps to maintain high $\mathrm{RH}$, high $\mathrm{CO}_{2}$ and low $\mathrm{O}_{2}$ levels. Such conditions keep down the rates of transpiration and respiration and permit partial gas exchange, thus preventing injury due to excess content of $\mathrm{CO}_{2}$. This in turn extended the longevity of cut roses when they are brought back to room temperature in the laboratory and evaluated for their vase life in distilled water. Jyothi and Balakrishnamoorthy (2000) and Singh and Mirza (2004) also reported similar observations with cellophane paper wrapping of cut roses.

\section{References}

Bhaskar, V.V., Rao, P.V. and Reddy, Y.N. 2005. Influence of germicides on the physiological and biochemical changes in the flower petals during vase life period of cut rose cv. First red. Indian Journal of Horticulture. 62(2): 171-174.

Bhattacharjee, S.K. 1997. Packaging of fresh cut flowers. Indian Horticulture. 41: 2327.

Buys, C. 1969. Leaves influence the vase life of cut flowers. Zierpflanzenbau 9: 639-640.

Halevy, A.H. and Mayak, S. 1979. Senescence and postharvest physiology of cut flowers. In: Horticultural Reviews-1. J Janick (ed.), Avi Publishing Company Inc., West Port, Connecticut, USA, pp 204-236.

Jyothi, L.J. and Balakrishnamoorthy, G. 2000. Effect of pulsing and packaging materials on postharvest life of rose cv. Happiness. South Indian Hort. 47: 361-363.

Panse, V.G. and Sukhatme, P.V. 1978. Statistical methods for agricultural workers. Indian Council of Agricultural Research Publications, New Delhi. $p p$. 108.

Singh, P.V. and Mirza, A.A. 2004. Postharvest life and quality of cut rose cultivar Super Star as influenced by packaging material. Journal of Ornamental Horticulture. 7(1): 58-63.

\section{How to cite this article:}

Vijaya Bhaskar, V. and Venkata Rao, P. 2018. Effect of Packaging Material on the Postharvest Life of Cut Rose cv. 'First Red'. Int.J.Curr.Microbiol.App.Sci. 7(01): 1019-1024. doi: https://doi.org/10.20546/ijcmas.2018.701.122 